\title{
Analisis Perspektif Pelaksanaan Magang dan Peluang Kerja dalam Menilai Kesiapan Kerja Mahasiswa
}

\author{
Eryd Saputra $^{1 *}$ Krismadinata $^{2}$ dan Nizwardi Jalinus ${ }^{3}$ \\ ${ }^{1}$ Culinary Management Study Program, Batam Tourism Polytechnic \\ ${ }^{2}$ Department of Electrical Engineering, Faculty of Engineering, State University of Padang \\ ${ }^{3}$ Postgraduate Program, Faculty of Engineering, State University of Padang \\ "Corresponding author, e-mail: saputra.eryd@gmail.com
}

\begin{abstract}
Abstrak-Tujuan dari makalah ini adalah untuk mengakaji bagaimana magang dapat melihat kesiapan kerja mahasiswa setelah menyelesaikan pendidikan. Pendekatan penelitian ini dengan mengeksplorasi persepsi mahasiswa tentang kesiapan kerja setelah program magang diselesaikan. Konsep kesiapan kerja adalah konsep dalam hal kejelasan peran, kemampuan dan motivasi. Hasil penelitian mahasiswa yang telah menyelesaikan magang, menilai secara positif atas segala aspek kesiapan kerja yang dibangun pada saat magang. Sehingga mereka mengerti apa yang diharapkan oleh pimpinan di tempat mereka magang. Mereka mampu secara efektif menerapkan keterampilan teknis dasar, keterampilan tingkat tinggi dan keterampilan profesional yang dibutuhkan oleh pimpinan tempat mereka magang.
\end{abstract}

Kata kunci: Motivasi, Kemampuan Kerja, Keterampilan, Magang, Kejelasan peran, Kesiapan kerja

\begin{abstract}
The purpose of this paper is to examine how internships can see the readiness of student work after completing education. This research approach explores students' perceptions about work readiness after the internship program is completed. The concept of work readiness is a concept in terms of clarity of roles, abilities and motivation. The research results of students who have completed an apprenticeship, assess positively on all aspects of work readiness built at the time of the internship. So they understand what is expected by the leadership in their place of internship. They are able to effectively apply the basic technical skills, high-level skills and professional skills needed by the leaders where they are apprenticed.
\end{abstract}

Keywords: Motivation, Work Ability, Skills, Internship, Clarity of roles, Work Readiness

\section{Pendahuluan}

Kemajuan teknologi telah sampai pada tahap terciptanya sebuah kecerdasan buatan. Kecerdasan buatan ini telah meciptakan persaingan yang ketat di kalangan tenaga kerja global, telah menimbulkan keprihatinan serius tentang masa depan pekerjaan dan keefektifan program vokasi dalam mempersiapkan mahasiswa secara memadai untuk bekerja. Studi ini, membahas bagaimana magang terlibat dalam perumusan prospek kerja lulusan, tepat setelah kelulusan mereka. Meski tidak ada standar definisi magang, bisa dikatakan bahwa secara umum, bahwa magang dapat dilihat sebagai pengalaman kerja praktis jangka pendek di mana mahasiswa menerima bidang tertentu yang menjadi minat mereka".

Salah satu tujuan utama magang adalah untuk memastikan transisi yang lancar dari dari masa pendidikan ke tempat kerja [9]. Program magang memberikan mahasiswa kesempatan untuk menguji kemampuan, kepercayaan, dan sikap mereka yang berkaitan dengan tugas kerja tertentu atau jalur karier [14]. Hal ini memungkinkan mahasiswa untuk menutupi kesenjangan antara kelas teori yang abstrak dan realitas kerja praktis. Mahasiswa diberi kesempatan untuk menerapkan apa mereka telah terima dalam pengaturan ruang kelas tradisional ke tempat kerja nyata dan memperoleh pandangan pragmatis tentang 
tantangan pekerjaan.

Program magang dapat memperkuat kompetensi teknis, meningkatkan keterampilan analitis dan yang paling penting, menumbuhkan kesadaran akan kebutuhan konstan akan kemampuan beradaptasi dan kreativitas dalam dunia yang terus berubah $[5,9]$. Penelitian saat ini semakin memperkaya aliran literatur ini dan berkontribusi pada tubuh pengetahuan yang menilai nilai pengalaman magang melalui lensa konsep "kesiapan kerja", berdasarkan data primer yang dikumpulkan dari mahasiswa Politeknik Pariwisata Batam yang telah menyelasaikan magang di industri perhotelan.

Mengidentifikasi berbagai manfaat yang diperoleh oleh mahasiswa setelah berpartisipasi pada kegiatan magang industri: mahasiswa meningkatkan kesempatan mereka untuk mencari pekerjaan, memungkinkan untuk mahasiswa memperoleh tawaran untuk bekerja penuh waktu posisi pekerjaan oleh perusahaan yang mempekerjakan mereka sebagai pekerja magang, memperoleh pengalaman seperti itu dapat memotivasi mereka untuk memilih jalur karier tertentu yang tidak diketahui oleh mereka sebelum magang, dan mendapatkan pandangan realistis tentang pekerjaan dan persyaratannya, dan memperoleh kejelasan tentang apa yang ingin mereka lakukan dalam karir kedepannya [16]. Sejalan dengan temuan di atas, peneliti lain, mengidentifikasi tiga jenis manfaat untuk lulusan: "(a) peningkatan kesempatan kerja (b) peningkatan keterampilan dan kompetensi, dan (c) yang terkait dengan dampak pada eksplorasi karier [23].

Dalam pembahasan yang sama, beberapa penelitian memberikan bukti bahwa mahasiswa melihat magang sebagai alat praktis yang akan memberi mereka lampu hijau untuk pekerjaan [4]. Lulusan muda yang berpartisipasi dalam program magang lebih mungkin untuk mendapatkan proposal kelanjutan pekerjaan dari perusahaan magang tempat mereka magang [28]. Menerima rata-rata kompensasi yang lebih tinggi dan lebih banyak tawaran pekerjaan [3, 9, 12], menemukan pekerjaan pertama mereka lebih cepat $[12,16]$. meningkatkan prospek karir masa depan mereka [26]. dan memperkuat atau mengklarifikasi minat mereka pada pekerjaan yang spesifik [24].

Kekhawatiran yang serius dimiliki pebisnis saat ini adalah sejauh mana calon karyawan memiliki keterampilan praktis yang diperlukan dan keahlian untuk memenuhi tantangan dari tempat kerja yang terus berkembang [5]. Hal ini umum bagi lulusan muda untuk tidak bisa mengatasi tekanan terkait tantangan pekerjaan [27]. Lulusan yang telah berpartisipasi dalam magang program-program sebelum wawancara tampak lebih menjanjikan dibandingkan dengan calon mahasiswa yang belum menyelesaikan magang [10].

Studi ini berkontribusi pada tubuh pengetahuan di atas yang mengeksplorasi sejauh mana magang lebih siap untuk memasuki pasar kerja [11, 13]. Itu meningkatkan pemahaman kita tentang peran magang untuk kelayakan kerja lulusan bisnis prospek. Untuk mencapai tujuan ini, studi ini menerapkan sebagai lensa analitiknya konsep "kesiapan kerja".

Konsep "kesiapan kerja" diadaptasi oleh kerangka kerja konseptual " kesiapan konsumen"digunakan dalam literatur pemasaran $[1,18]$, yang landasan teori dapat ditemukan dalam teori organisasi [25]. Organisasi [10] menyatakan bahwa perilaku karyawan bergantung pada cara memahami tentang bagaimana mereka diharapkan untuk melakukan sesuatu yang sesuai dengan harapan, serta adanya imbalan dari kemampuan dalam menyelesaikannya. Dalam literatur pemasaran, perilaku pelanggan setiap kali pelanggan dilihat sebagai kontributor produksi dan pengiriman layanan ditemukan dan dibentuk oleh tiga aspek pertimbangan: kejelasan peran, motivasi dan kemampuan [1]. Studi ini menunjukkan bahwa konsep "kesiapan pelanggan" di atas dapat bermanfaat dalam mengeksplorasi efektivitas program magang untuk kelulusan kerja. Secara khusus, itu akan berguna dalam mengukur kesiapan magang atau lulusan untuk pekerjaan setelah mereka miliki menyelesaikan program magang. Untuk mencapai tujuan ini, penelitian ini mengadaptasi "kesiapan pelanggan" konsep [1, 18] ke dalam konteks magang. Itu dikonseptualisasikan " kesiapan bekerja" sebagai suatu kondisi atau keadaan dimana lulusan bersiap mencari pekerjaan. "Kesiapan kerja" terdiri dari tiga pilar: kejelasan peran, motivasi dan kemampuan.

Perlu diperhatikan bahwa tiga pilar "kesiapan" telah dibahas dalam literatur magang dengan cara yang sedikit demi sedikit dan tersebar. Untuk yang terbaik dari pengetahuan, belum ada upaya sejauh ini untuk menyajikan ketiga dimensi dalam acara bersatu. Penelitian ini berupaya untuk memberikan pandangan terpadu tentang faktorfaktor yang mempengaruhi prospek kelayakan kerja lulusan sebagai hasil dari program magang dengan pengenalan konsep "kesiapan kerja". 
Magang memungkinkan mahasiswa untuk mengembangkan keterampilan generik dan spesifik mereka, sambil mendapatkan pengalaman kerja. Mengenai keterampilan kerja, beberapa kategorisasi dapat ditemukan dalam literatur. Mengklasifikasikan keterampilan dalam empat kategori: keterampilan akademik dasar (mendengarkan dan berbicara); keterampilan berpikir tingkat tinggi (penalaran, pemecahan masalah dan kreativitas); keterampilan interpersonal dan kerja tim; dan karakteristik dan sikap pribadi (harga diri, motivasi dan tanggung jawab) [20]. Meninjau literatur tentang keterampilan yang paling penting di antara kriteria perekrutan yang digunakan untuk memilih lulusan baru: komunikasi keterampilan (presentasi lisan, penulisan proposal dan komunikasi tertulis), keterampilan akademik (keterampilan analitis, aplikasi komputer, pemikiran kreatif, pencarian dan masalah informasi pemecahan), keterampilan kepemimpinan (kepemimpinan / kerja tim dan pembangunan hubungan) dan pekerjaan keterampilan akuisisi (penulisan resume, wawancara kerja, dan jejaring kerja) [12]. Studi baru [6] tentang keterampilan yang dicari oleh perusahaan yang mempekerjakan menggambarkan bahwa "keterampilan generik (manajemen waktu, bekerja dalam tim, perhatian terhadap detail), kemampuan mental umum, pengetahuan khusus subjek, kemauan untuk bekerja, sikap dan perilaku, dan responsif terhadap umpan balik " adalah kriteria utama yang dipertimbangkan oleh perusahaan untuk merekrut dan mengevaluasi prospek kelayakan kerja para kandidat pekerja.

Melalui partisipasi mereka dalam program magang, para mahasiswa memperoleh pemahaman tentang kecocokan mereka di sektor bisnis atau profil pekerjaan tertentu. Akibatnya, minat mereka untuk bekerja di jenis bisnis atau sektor tertentu dapat diperkuat atau ditingkatkan lebih jauh [24]. Oleh karena itu, minat tulus mahsiswa tentang aktivitas bisnis atau domain dapat dianggap sebagai hadiah intrinsik yang memicu kinerja mereka dan meningkatkan pengalaman mereka secara keseluruhan dalam pengaturan kerja. Literatur lain masih ada juga menunjukkan bahwa perasaan kepuasan positif dengan rekan kerja, penyelia dan pekerjaan sendiri dialami oleh pekerja magang $[7,16]$ hadiah juga sangat memotivasi mereka untuk memanfaatkan waktu mereka selama program magang. Efektivitas magang diharapkan akan ditingkatkan ketika harapan yang jelas, tugas, tanggung jawab dan hasil untuk pekerja magang didefinisikan $[16,22]$, serta harapan yang jelas dari kewajiban implisit dan eksplisit pengusaha [15] terpenuhi.

\section{MetodA}

Studi ini menggunakan survey pada mahasiswa Politeknik Pariwasata Batam yang telah melaksanakan magang di hotel dalam dan luar negeri berjumlah 55 orang. Pernyataan yang ada pada kuesioner mengunakan poin tipe Likert. Pernyataan (di mana 1: nilai terendah; 5: nilai tertinggi). Kuesioner diujikan untuk susunan kata, kejelasan dan kelengkapan oleh peneliti dan dilakukan pada lima mahasiswa Politeknik Pariwisata Batam.

Pada penelitian ini terdapat 25 pernyataan, seperti di tabel 1 .

Tabel 1. Item Inti Pernyataan

\begin{tabular}{|l|}
\hline \multicolumn{1}{|c|}{ Pernyataan } \\
\hline Q1. Saya merasa yakin tentang cara menggunakan \\
keterampilan saya secara efektif di tempat kerja \\
\hline Q2. Saya tahu apa yang diharapkan dari saya jika saya \\
menggunakan keterampilan saya di tempat kerja \\
\hline $\begin{array}{l}\text { Q3. Langkah-langkah dalam proses menggunakan } \\
\text { keterampilan jelas bagi saya }\end{array}$ \\
\hline Q4Komunikasi secara tertulis \\
\hline Q5 Komunikasi verbal \\
\hline Q6 Bekerja sebagai anggota tim \\
\hline Q7 Kolaborasi untuk menyelesaikan tugas grup \\
\hline Q8 Bekerja dengan orang-orang dari beragam asal \\
\hline Q9 Identifikasi masalah \\
\hline Q10 Berpikir kreatif dan inovatif \\
\hline Q11 Buat keputusan yang tepat \\
\hline Q12 Keputusan tepat waktu \\
\hline Q13 Selesaikan tugasnya tepat waktu \\
\hline Q14 Selesaikan tugas tanpa pengawasan \\
\hline Q15 Mengatasi ketidakpastian \\
\hline Q16 Bekerja di bawah tekanan \\
\hline Q17 Menerima tanggung jawab \\
\hline Q18 Pengakuan \\
\hline Q19 Prestasi \\
\hline Q20 Tanggung jawab \\
\hline Q21 Peluang untuk pertumbuhan \\
\hline Q22 Kebijakan perusahaan \\
\hline Q23 Lingkungan kerja yang baik \\
\hline Q24 Gaji yang baik \\
\hline Q25 Tantangan dalam pekerjaan \\
\hline
\end{tabular}

Pada tabel 1, 25 kuesioner yang digunakan untuk mendapatkan data tiga variabel yang ditelti: 1) kejelasan peran; 2) kemampuan; 3) motivasi. Variabel kejelasan peran (VKP) mempunyai pernyataan Q1-Q3, kemampuan (VK) terbagi menjadi tiga sub variabel (keterampilan teknik dasar, keterampilan berpikir tingkat tinggi, keahlian professional) yang mempunyai 
pernyataan Q4-Q17, variabel motivasi (VM) terdiri dari dua sub varaibel (motivasi intrinsic dan motivasi ekstrinsik) yang mempunyai pernyataan Q18-Q25.

\section{HASIL DAN PEMBAHASAN}

Hasil penelitian yang telah dilakukan pada mahasiswa Politeknik Pariwisata Batam tentang bagaimana magang memberikan gambaran yang memperjelas jenis dan kompleksitas pekerjaan yang akan mereka tekuni, memperluas jaringan untuk mempermudah mereka setelah menyelesaikan pendidikan. Hasil yang diperoleh dari kuesioner yang diisi oleh mahasiswa seperti ditabel 2.

Tabel 2. Hasil Kuesioner Secara Keseluruhan

\begin{tabular}{|l|c|c|c|}
\hline Pernyataan & $\begin{array}{c}\text { Responden } \\
(\mathrm{n})\end{array}$ & Rata-rata & Median \\
\hline Q1 & 55 & 4.11 & 4 \\
\hline Q2 & 55 & 4.15 & 4 \\
\hline Q3 & 55 & 3.76 & 4 \\
\hline Q4 & 55 & 4.11 & 4 \\
\hline Q5 & 55 & 4.20 & 4 \\
\hline Q6 & 55 & 3.75 & 4 \\
\hline Q7 & 55 & 4.11 & 4 \\
\hline Q8 & 55 & 3.38 & 3 \\
\hline Q9 & 55 & 4.24 & 4 \\
\hline Q10 & 55 & 3.58 & 4 \\
\hline Q11 & 55 & 4.07 & 4 \\
\hline Q12 & 55 & 3.96 & 4 \\
\hline Q13 & 55 & 3.42 & 3 \\
\hline Q14 & 55 & 3.67 & 4 \\
\hline Q15 & 55 & 4.11 & 4 \\
\hline Q16 & 55 & 4.18 & 4 \\
\hline Q17 & 55 & 3.18 & 3 \\
\hline Q18 & 55 & 4.09 & 4 \\
\hline Q19 & 55 & 3.89 & 4 \\
\hline Q20 & 55 & 4.07 & 4 \\
\hline Q21 & 55 & 3.33 & 3 \\
\hline Q22 & 55 & 3.91 & 4 \\
\hline Q23 & 55 & 3.67 & 4 \\
\hline Q24 & 55 & 4.05 & 4 \\
\hline Q25 & 55 & 4.20 & 4 \\
\hline & & &
\end{tabular}

Pada tabel 2 menjelaskan keseluruhan hasil kuesioner dengan nilai rata-rata setiap item dan mediannya.

\section{A. Kejelasan peran}

Sejauh tanggapan peserta magang terhadap aspek kejelasan peran, menunjukkan hasil responden rata-rata setuju dengan kejelasan peran yang mereka dapatkan telah magang dilakukan.

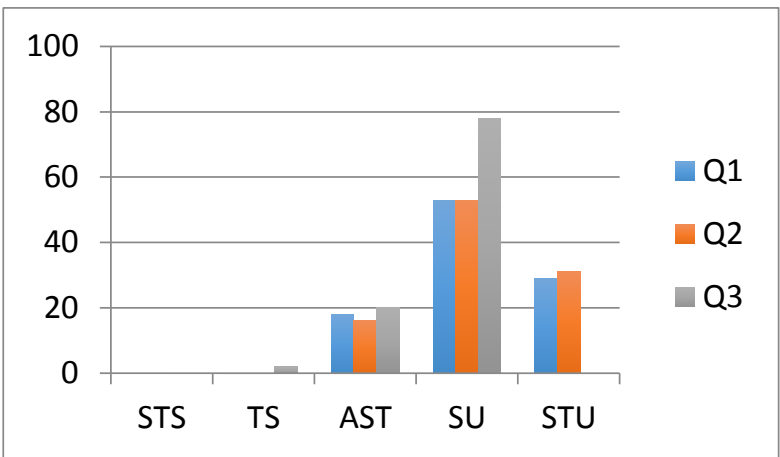

Gambar 1. Persentase Kejelasan Peran

Pada gambar 1 tentang kejelasan peran secara keseluruhan pernyataan Q1, Q2, Q3 menunjukkan nilai yang positif, dan terdapat nilai persentase Q3 (langkah-langkah dalam proses menggunakan keterampilan jelas bagi saya) memperoleh nilai tertinggi yaitu 78\%. Hal ini dapat diartikan bahwa mahasiswa merasa yakin tentang langkah kerja yang mereka lakukan tepat pada saat mereka magang.

\section{B. Keterampilan}

Sejauh tanggapan peserta magang terhadap aspek keterampilan, menunjukkan hasil responden rata-rata setuju dengan keterampilan yang mereka terapkan pada saat magang.

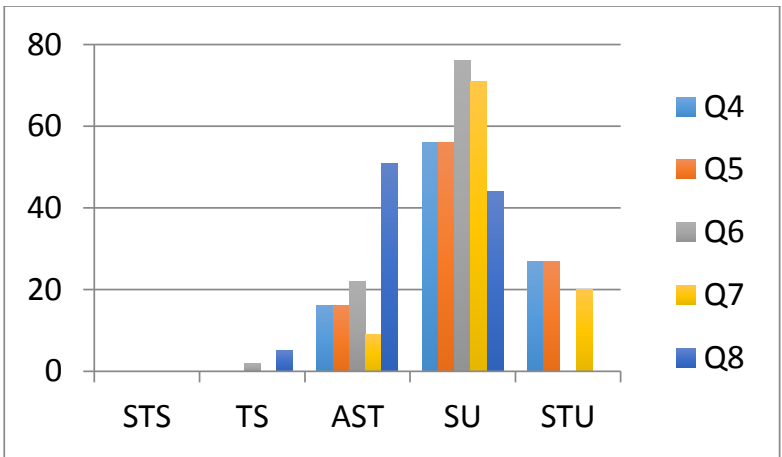

Gambar 2. Persentase Kemampuan (Keterampilan Teknik Dasar)

Pada gambar 2 tentang kemampuan (keterampilan teknis dasar) secara keseluruhan pernyataan Q4, Q5, Q6, Q7, Q8 menunjukkan nilai yang positif, dan terdapat nilai persentase Q6 memperoleh nilai tertinggi yaitu $76 \%$ setuju mereka dapat bekerja sebagai anggota tim. Hal ini dapat diartikan bahwa mahasiswa merasa yakin mereka dapat bekerja sebagai anggota tim adalah keterampilan yang akan menjadi modal mereka setelah selasai pendidikan. 


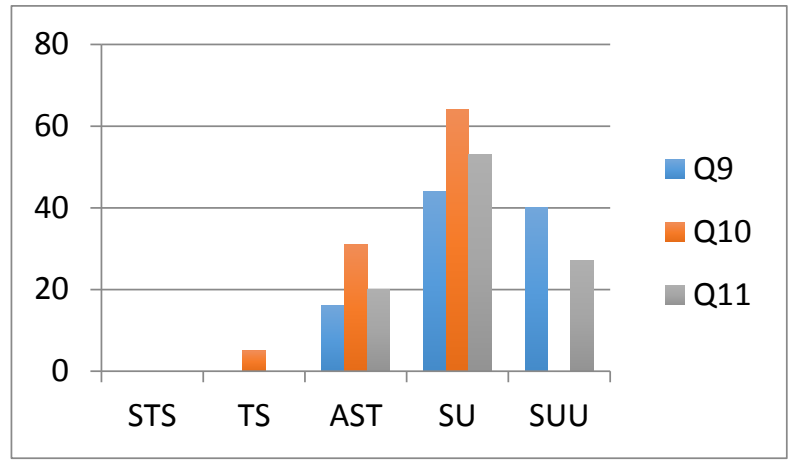

Gambar 3. Persentase Kemampuan (Keterampilan Tingkat Tinggi)

Pada gambar 3 tentang kemampuan (keterampilan tingkat tinggi) secara keseluruhan pernyataan Q9, Q10, Q11, menunjukkan nilai yang positif, dan terdapat nilai persentase Q10 memperoleh nilai tertinggi yaitu $64 \%$, mereka berpikir kreatif dan inovatif menjadi sangat penting pada saat mereka magang. Hal ini dapat diartikan bahwa mahasiswa merasa yakin berpikir kreatif dan inovatif adalah keterampilan yang akan menjadi modal mereka setelah selasai pendidikan.

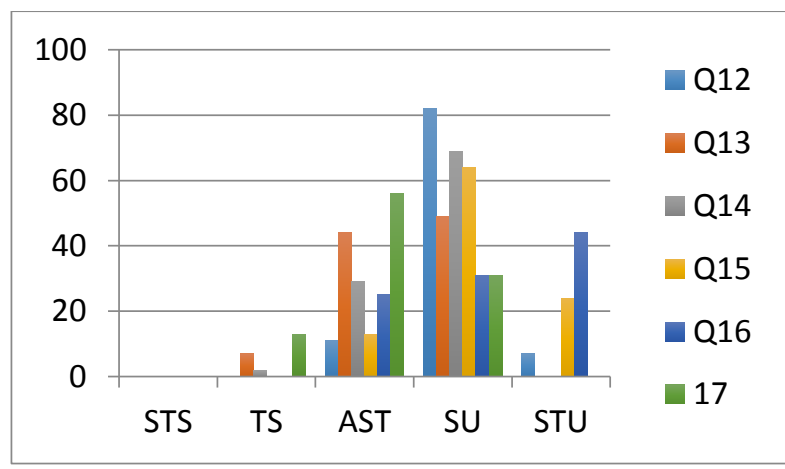

Gambar 4. Persentase Kemampuan (Keahlian Profesional)

Pada gambar 4 tentang kemampuan (keahlian profesional) secara keseluruhan pernyataan Q12, Q13, Q14, Q15, Q16, Q17 menunjukkan nilai yang positif, dan terdapat nilai persentase Q12 memperoleh nilai tertinggi yaitu $82 \%$, mereka berpikir keputusan tepat waktu menjadi sangat penting pada saat mereka magang. Hal ini dapat diartikan bahwa mahasiswa merasa yakin keputusan tepat waktu adalah keterampilan yang akan menjadi modal yang baik untuk mereka setelah selasai pendidikan.

Selain itu, sampel responden kemampuan untuk bekerja, menempatkan lebih besar pentingnya faktor-faktor keahlian profesional daripada yang keterampilan tingkat tinggi dan keterampilan teknik dasar. Faktor-faktor yang ditemukan pada kemampuan mereka sebagian besar " keputusan tepat waktu".

\section{Motivasi}

Sejauh tanggapan peserta magang terhadap aspek motivasi, menunjukkan hasil responden rata-rata setuju dengan motivasi yang mereka dapatkan setelah magang dilakukan.

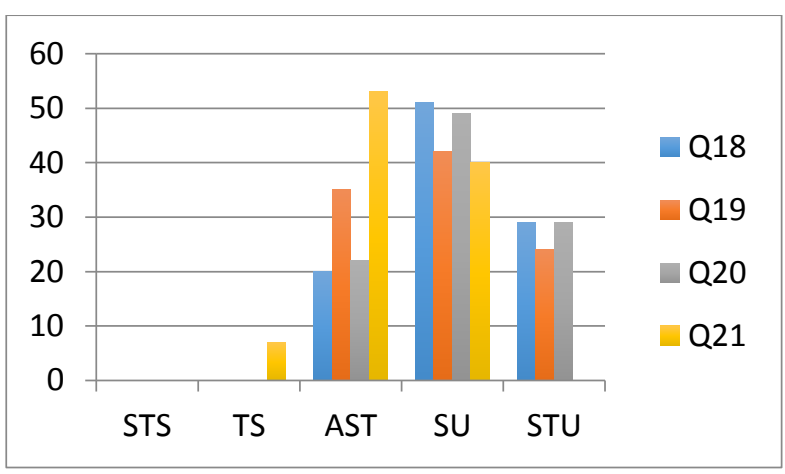

Gambar 5. Motivasi (Intrinsik)

Pada gambar 5 tentang kemampuan (keterampilan tingkat tinggi) secara keseluruhan pernyataan Q18, Q19, Q20, Q21 menunjukkan nilai yang positif, dan terdapat nilai persentase Q21 memperoleh nilai tertinggi yaitu 53\%, mereka berpikir bahwa peluang untuk pertumbuhan menjadi sangat penting pada saat mereka magang. Hal ini dapat diartikan bahwa mahasiswa merasa yakin peluang untuk pertumbuhan menjadi motivasi yang besar untuk memperluas wawasan mereka pada saat magang.

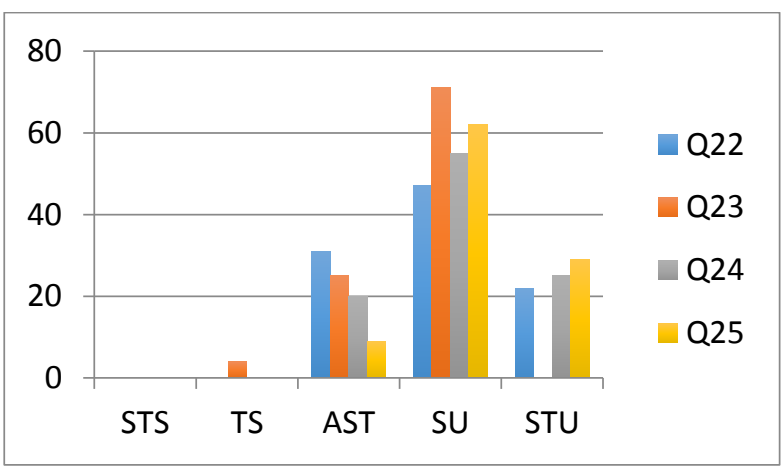

Gambar 6. Motivasi (Ekstrinsik)

Pada gambar 6 tentang kemampuan (keterampilan tingkat tinggi) secara keseluruhan pernyataan Q22, Q23, Q24, Q25 menunjukkan nilai yang positif, dan terdapat nilai persentase Q23 memperoleh nilai tertinggi yaitu $71 \%$, mereka berpikir bahwa lingkungan kerja yang baik menjadi sangat penting pada saat mereka magang. Hal ini dapat diartikan bahwa mahasiswa 
merasa lingkungan kerja yang baik dapat menjadi motivasi yang besar untuk mereka, pada saat magang.

Selain itu, sampel responden termotivasi untuk bekerja, menempatkan lebih besar pentingnya faktor-faktor ekstrinsik daripada yang intrinsik. Faktor-faktor yang ditemukan memotivasi mereka sebagian besar lingkungan kerja yang baik dan hasil yang terendah adalah kebijakan perusahaan.

Makalah ini mengeksplorasi nilai pengalaman magang melalui lensa Konsep "kesiapan kerja". Menggambar pada survei mahasiswa yang berpartisipasi dalam magang di Indonesia atau di luar negeri, itu menyelidiki persepsi mereka mengenai tingkat kesiapan mereka untuk memasuki pasar kerja. Sejalan dengan literatur yang masih ada yang menganalisis manfaat magang bagi siswa [3, 9, 12, 23], temuan penelitian ini menunjukkan bahwa program magang meningkatkan siswa prospek kerja, karena mereka cukup untuk mempersiapkan mereka pada penyesuaian dengan realitas kehidupan kerja.

Mahasiswa menilai secara positif pengalaman magang mengenai keseluruhan pemahaman (apa yang diperlukan untuk bekerja dengan baik di tempat kerja), motivasi (apa yang akan memotivasi mereka untuk terlibat dalam perilaku yang diinginkan di tempat kerja) dan keterampilan (kompetensi utama untuk melakukan tertentu tugas kerja) yang diperlukan untuk dapat dipekerjakan di tempat kerja. Pengalaman magang memungkinkan mereka untuk menyadari bagaimana mereka dapat unggul di tempat kerja, mengidentifikasi apa penting bagi mereka untuk terlibat penuh dalam penyelesaian aktivitas dan kerja, membentuk perasaan lebih percaya diri tentang cara menggunakan keterampilan mereka secara efektif di tempat kerja.

Pertama, kejelasan peran dianggap penting. Pemahaman yang jelas tentang apa yang diharapkan dari magang membuat mereka lebih efektif dan puas. Mereka menjadi sadar akan apa mereka harus memprioritaskan, mengenal beberapa akuntabilitas dan pelaporan masalah dan menyadari perlunya umpan balik dan penyesuaian. Memang, kejelasan seperti di peran dan tanggung jawab yang ditanggung oleh pekerja magang, meningkatkan kemungkinan untuk mereka menjadi efektif dalam magang dan kerja $[13,16]$.

Kedua, peluang untuk pertumbuhan dan lingkungan kerja adalah penghargaan yang paling tinggi dihargai oleh responden. Baik penghargaan intrinsik dan ekstrinsik penting dalam memotivasi magang untuk terlibat dalam perilaku yang diinginkan dan merasakan kepuasan darinya keseluruhan pengalaman magang $[7,16]$. Ketiga, lebar berbagai keterampilan yang sangat diinginkan oleh perusahaan mempekerjakan masa depan ditemukan dikembangkan selama magang. Konsisten dengan temuan penelitian sebelumnya $[6,12]$, komunikasi verbal dan tertulis, efektif kolaborasi, bekerja sebagai anggota tim, menggunakan teknologi, pemecahan masalah, waktu manajemen, mengambil inisiatif dan memikul tanggung jawab adalah beberapa bidang keterampilan bahwa responden melaporkan bahwa mereka telah banyak berlatih melalui penempatan mereka dalam mempekerjakan perusahaan.

Temuan penelitian ini memiliki implikasi untuk semua pemangku kepentingan yang terlibat: mahasiswa, kampus dan industri, contoh. perusahaan yang menawarkan penempatan. mahasiswa yang memiliki pemahaman yang jelas tentang alasan mereka harus berinvestasi dalam magang, serta apa yang harus mereka lakukan untuk mendapatkan manfaat terbesar dari proses magang tersebut, dapat meningkatkan prospek kerja. Memang, lensa "kesiapan kerja" yang disajikan di sini dapat dianggap sebagai indikator yang sangat baik dari "kesadaran magang" yang merupakan tingkat dimana siswa dapat menilai berapa magang yang dihasilkan mereka siap memasuki pasar kerja. Akhirnya, program magang dapat mendukung bisnis atau pengusaha untuk menemukan kandidat yang tepat untuk menjadi pekerja ditempat mereka. Perusahaan dapat bekerja sama dengan kampus atau lembaga akademis lainnya untuk meningkatkan atau memperbarui keterampilan mahasiswa agar prospektif mereka menangani kebutuhan tempat kerja yang berkembang secara global.

\section{KESIMPULAN}

Mahasiswa menilai secara positif pengalaman magang yang mencakup kejelasan peran secara keselurahan, motivasi, dan keterampilan (kompetensi utama untuk melakukan tertentu tugas kerja) yang diperlukan untuk dapat dipekerjakan di tempat kerja magang pengalaman memungkinkan mereka untuk menyadari bagaimana mereka dapat unggul di tempat kerja, mengidentifikasi apa penting bagi mereka untuk terlibat penuh dalam penyelesaian aktivitas dan perasaan kerja lebih percaya diri tentang cara menggunakan keterampilan mereka secara efektif 
di tempat kerja yang akan mereka pilih setelah lulus kuliah.

\section{DAftar Pustaka}

[1] Bonett, D.G. (2002), "Sample size requirements for testing and estimating coefficient alpha", Journal of Educational and Behavioral Sciences, Vol. 27 No. 4, pp. 335-340.

[2] Bowen, D.E. (1986), "Managing customers as human resources in service organizations", Human Resource Management, Vol. 25 No. 3, pp. 371-383.

[3] Callanan, G. and Benzing, C. (2004), "Assessing the role of internships in the career-oriented employment of graduating college students", Education + Training, Vol. 46 No. 2, pp. 82-89.

[4] Cannon, J.A. and Arnold, M.J. (1998), "Student expectations of collegiate internship programs in business: a 10-year update", Journal of Education for Business, Vol. 73 No. 4, pp. 202-205

[5] Chen, C.T., Hu, J.L., Wang, C.C. and Chen, C.F. (2011), "A study of the effects of internship experiences on the behavioural intentions of college students majoring in leisure management in Taiwan", Journal of Hospitality Leisure Sport \& Tourism Education, Vol. 10 No. 2, pp. 61-73.

[6] Chhinzer, N. and Russo, A.M. (2018), "An exploration of employer perceptions of graduate student employability", Education + Training, Vol. 60 No. 1, pp. 104-120.

[7] Cho, M. (2006), "Student perspectives on the quality of hotel management internships", Journal of Teaching in Travel \& Tourism, Vol. 6 No. 1, pp. 61-76

[8] Churchill, G.A. (1979), “A paradigm for developing better measures of marketing constructs", Journal of Marketing Research, Vol. 16 No. 1, pp. 64-73.

[9] Coco, M. (2000), "Internships: a try before you buy arrangement", SAM Advanced Management Journal, Vol. 65 No. 2, pp. 41-47.

[10] Divine, R.L., Linrud, J.K., Miller, R.H. and Wilson, J.H. (2007), "Required internship programs in marketing: benefits, challenges and determinants of fit", Marketing Education Review, Vol. 17 No. 2, pp. 4552.
[11] Gault, J., Leach, E. and Duey, M. (2010), "Effects of business internships on job marketability: the employers' perspective", Education + Training, Vol. 52 No. 1, pp. 76-88.

[12] Gault, J., Redington, J. and Schlager, T. (2000), "Undergraduate business internships and career success: are they related?", Journal of Marketing Education, Vol. 22 No. 1, pp. 45-53.

[13] Hite, R. and Bellizzi, J. (1986), "Student expectations regarding collegiate internship programs in marketing", Journal of Marketing Education, Vol. 8 No. 3, pp. 4149.

[14] Howery, C. (1983), “Undergraduate education", in Freeman, H., Dynes, R.R. and Whyte, W.F. (Eds), Applied Sociology: Roles and Activities of Sociologists in Diverse Settings, Jossey-Bass, San Francisco, pp. 322-347.

[15] Hurst, J.L., Good, L.K. and Gardner, P. (2012), "Conversion intentions of interns: what are the motivating factors?", Education + Training, Vol. 54 No. 6, pp. 504-522.

[16] Knouse, S.B. and Fontenot, G. (2008), "Benefits of the business college internship: a research review", Journal of Employment Counseling, Vol. 45 No. 2, pp. 61-66.

[17] Knouse, S.B., Tanner, J.R. and Harris, E.W. (1999), "The relation of college internships, college performance, and subsequent job opportunity", Journal of Employment Counseling, Vol. 36 No. 1, pp. 35-43.

[18] Meuter, M.L., Bitner, M.J., Ostrom, A.L. and Brown, S.W. (2005), "Choosing among alternative service delivery modes: an investigation of customer trial of selfservice technologies", Journal of Marketing, Vol. 69 No. 2, pp. 61-83.

[19] Nunnally, J. (1978), Psychometric Theory, 2nd ed., McGraw-Hill, New York, NY.

[20] O’Neil, H.F. Jr (1997), Workforce Readiness - Competencies and Assessment, Lawrence Erlbaum Associates, London.

[21] Peter, J.P. (1981), "Construct validity: a review of basic issues and marketing practices", Journal of Marketing Research, Vol. 18 No. 2, pp. 133-145.

[22] Rothman, M. (2007), "Lessons learned: advice to employers from interns", Journal of Education for Business, Vol. 82 No. 3, pp. 140-144. 
[23] Sanahuja Vélez, G. and Ribes Giner, G. (2015), "Effects of business internships on students, employers, and higher education institutions: a systematic review", Journal of Employment Counseling, Vol. 52 No. 3, pp. 121-130.

[24] Varghese, M.E., Parker, L.C., Adedokun, O., Shively, M., Burgess, W., Childress, A. and Bessenbacher, A. (2012), "Experiential internships: understanding the process of student learning in small business internships", Industry and Higher Education, Vol. 26 No. 5, pp. 357-367.

[25] Vroom, V.H. (1964), Work and Motivation, Wiley, New York, NY.

[26] Wan, C.S., Yang, J.T., Cheng, S.Y. and Su, C. (2013), "A longitudinal study on internship effectiveness in vocational higher education", Educational Review, Vol. 65 No. 1, pp. 36-55.

[27] Wang, Y.F. (2002), "Evolution of higher education in hospitality in Taiwan", Journal of Human Ecology and Technology, Vol. 3 No. 4, pp. 453-464.

[28] Zhao, H. and Liden, R.C. (2011), "Internship: a recruitment and selection perspective", Journal of Applied Psychology, Vol. 96 No. 1, pp. 221-229.

\section{Biodata Penulis}

Eryd Saputra, S.Par., M.M., M.Sc, lahir di Bukittingi, 14 Februari 1988, menyelesaikan S1 di Sekolah Tinggi Pariwisata Ambarrukmo Yogyakarta, lanjut studi S2 Teknik Aristektur Universitas Gadjah Mada, dan Mengambil S2 di Sekolah Tinggi Ekonomi Pariwisata Indonesia, saat ini menjadi staf mengajar di Politeknik Pariwsata Batam sejak 2017- hingga saat ini.

Krismadinata, lahir di Padang pada tanggal 11 September 1977. Lulus dengan gelar Sarjana Tenik dari Universitas Andalas pada tahun 2000. Memperoleh gelar Magister Teknik dari Institut Teknologi Bandung (ITB) pada tahun 2004, dan S3 di Universiti Malaya Kuala Lumpur pada tahun 2012.

Nizwardi Jalinus, lahir di Palembang pada tanggal 22 Agustus 1952. Menyelesaikan program sarjana Pendidikan Teknik Mesin di Universitas Negeri Padang pada tahun 1978 dan program Doktor Pendidikan Vokasi pada tahun 1998 di University of Tasmania, Australia. Saat ini menjadi Guru besar di Fakultas Teknik Universitas Negeri Padang. 